\title{
Corpus-based studies of Middle English adverb largely: syntax and information-structure
}

\author{
Olena Andrushenko
}

DOI: 10.18355/XL.2021.14.02.05

\begin{abstract}
The study aims at exploring the adverb largely in late Middle English based on the Corpus of Middle English Prose and Verse, in terms of its functioning as a sentence Focus marker. The article considers syntactic changes in English from the language with V2 tendencies to the one with verb-medial order. Such differences make sentence information structure disrupted, and new elements arise in the language as 'therapy.' The assumption made in this paper is as follows: the word largely emerging in English in ca. 1200 starts functioning as a focusing adverb in 1400 as a result of the shift in the main word order patterns. Moreover, investigating late Middle English syntactic structure and taking into account different types of foci based on information structure tagging throughout the Corpus, the study found that positional variations of adverb largely are used as a mechanism of marking a peculiar type of Focus and are governed by its position in relation to the word it modifies.
\end{abstract}

Key words: adverb, word order, information structure, Focus, Topic

\section{Introduction}

Focusing adverbs form a class of words used to focus the utterance content. They highlight a constituent of any syntactic category such as NPs, verbs, VPs, etc. Traditionally, this class was singled out by Quirk et al. (1985: 604). Further studies reveal that focusing adverbs fall into two major categories: restrictive, which are, in turn, subdivided into exclusives (only, alone, just) and particularizers (especially, exactly, largely), and additives (even, too, also). When it comes to the question of terminology, there is no unanimity among linguists, i.e., this class is regarded either as a subclass of particles (Helbig 1988, Foolen 1993) or as a subclass of adverbs (Gast\&van der Auwera 2011, Forker 2016). The present study proposes to confine to the term "focusing adverbs" taking into account their syntactic function and morphological structure with the predominance of the -ly suffix in this class (Andrushenko 2017).

The aim of the current investigation is to explore the emergence of particulizer largely in Middle English as one of the focusing adverbs. Historical corpora and dictionaries reveal that it is attested in c. 1200 being derived from adjective large (from Old French large "broad, wide; generous, bounteous" (12c.), from Latin largus "abundant, copious, plentiful; bountiful, liberal in giving, generous" (source also of Spanish largo "long," Italian largo "wide"). This adverb originally rendered the meaning of "liberally, generously, bountifully;" also "in large measure; abundantly" (1).

(1) Lutel perf pu carien...pet he nule gleadliche ifinde pe largeliche al pet te

bihoueð. (c. 1225 (?c.1200) HMaid.(Bod 34) 26/408)

The meaning of "extensively", "to a great extent", characteristic of this adverb in Modern English, is approximately attested only in c. 1400 (2).

(2) I haf synned largely In many synnes sere. (1459 LFMass Bk. (Cmb

Cg.5.31)

Middle English studies show that out of 378 examples found in Corpus of Middle English Prose and Verse (ME Corpus), only ca $37.6 \%$ of instances reveal the meaning of largely as a focusing adverb. 
When these data are compared with definitions from Modern English Dictionary and the instances from British National Corpus (BNC) where largely is represented by 7203 tokens, the only meaning rendered by the adverb is "to a great degree, generally" (3)-(4), thus, it exclusively functions as a particulizer.

(3) And er, that we have, we have been largely on target with those items that were put forward, as has been the objectives and, and some of the targeting of the agreement itself (Shropshire County Council Social Services Committee: committee meeting (Pub/instit. Rec. on 11 Jan 1994 with 8 partics, 351 utts, BNC)

(4) But these largely managerial changes hardly amounted to a fundamental review; rather they were concerned to promote competition and value for money. (Thatcherism and British politics. Kavanagh, Dennis. Oxford: OUP, 1990, pp. 209-319. 1580 s-units, BNC)

Findings from ME Corpus also indicate that the adverb can occupy either a premodifying (5) or a post-modifying position (6) without any regularity in terms of word order patterns peculiar for the period.

(5) in that dai a lomb schal be fed largeli->in thi pos|sessioun. (A paralleltext print of Chaucer's Troilus and Criseyde)

(6) And men syngynge in her voices alargiden*. [alargiden; that is, heri|eden God <-largeli. (A parallel-text print of Chaucer's Troilus and Criseyde)

These observations triggered the questions, firstly, concerning the factors that facilitated the change in the adverbial meaning turning it into a Focus marker in further centuries of the language development and, secondly, whether there is any consistency in the adverb placement with regard to word-order patterns. The initial hypothesis made is as follows: the rise of the additional meaning of largely may have evolved due to: 1) the changes in syntax throughout the ME period from the language with predominant V2-constain, which was the case in Old English (OE) and Early Middle English, to the one with verb-medial word order in Late Middle English; 2) the impact of these changes on the information structure of the sentence, which got disrupted, causing new structures to arise in the language as 'therapy' (Los\&van Kemenade 2012). Thus, focusing particulizer largely emerges in Late Middle English to syntactically mark Focus constituents, which due to the loss of minimal morphology and more rigid syntax are bound to occupy mostly a post-verbal position. To prove the hypothesis, it is proposed 1) to give a general overview of word order patterns in Old and Middle English and analyze the changes in the clause structure; 2) investigate the patterns with adverb largely in ME Corpus with reference to information structure and its mapping into syntax with reference to various types of foci.

\section{Literature review}

\subsection{Word order in Old English}

Old English is commonly termed as the language with verb-second constraint. Findings show that the syntax in the records of VII-XI cen. resembles V2 languages in which T-initial structures occur in root and embedded clauses (Taylor\&Ringe 2014: 396). The finite verb in the clause always moves out of VP to the head of TP, while the subject moves from spec,VP to spec, TP or remains in situ (Fig. 1). 


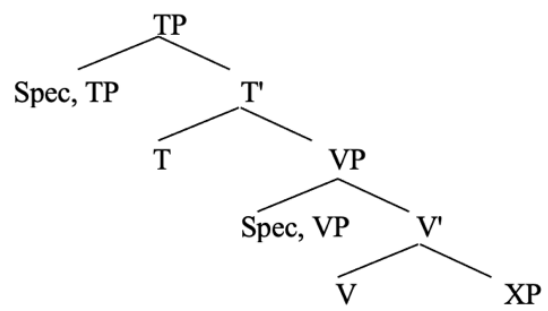

Figure 1. Old English Sentence Structure (Taylor\&Ringe 2014: 393).

Extensive research has proved $\mathrm{OE}$ is not a clear-cut case of $\mathrm{V} 2$ language, since it has a V2/V3 alteration that has been a subject of substantial investigation (see: van Kemenade 1987; Taylor 2014, Walkden 2014). Sentence (7) is the example of V2, whilst (8) of $\mathrm{V} 3$ respectively.

(7) ba genam hine se awyrgda gast

then took him the accursed spirit

'Then the accursed spirit took him.' (BlHom, 27.8.358)

(8) For prim pingum Hælend eode on westen

For three reasons Savior went into wilderness

'For three reasons, the Savior went into the wilderness.' (BlHom, 29:18)

Studying the distribution of word order patterns throughout Old English K. Bech argues that while V2 is a characteristic feature of OE, it is not completely dominant, and in fact word order is quite heterogeneous (Bech 2001). This may also be proven by our data from $9^{\text {th }}$ century records where no dominant word order is registered although SVO pattern is more frequently used (Table 1).

\begin{tabular}{l|l|l|l|l|l|l|l|l|l|l}
\hline WO type & SVO & VSO & SOV & VOS & OSV & OSOV & OVS & XVOS & $\begin{array}{l}\text { OV, } \\
\text { VO }\end{array}$ & $\begin{array}{l}\text { Neg } \\
\text { s-ces }\end{array}$ \\
\hline Quantity & 269 & 209 & 73 & 11 & 15 & 2 & 21 & 2 & 12 & 10 \\
\hline$\%$ & 43.1 & 33.49 & 11.7 & 1.76 & 2.4 & 0.33 & 3.36 & 0.33 & 1.92 & 1.61 \\
\hline
\end{tabular}

Table 1. WO Patterns of Old English Simple Sentence of IX cen.

Various investigations indicate that the proportion of typical verb-second clauses (SVX, XVS, XV, SV1XV2) reaches 71.3\%, hence, Old English demonstrates V2 tendencies (Bech 2001).

The inconsistency of word-order patterns made linguists draw a conclusion that word order variations in this period are tightly connected with information-structural factors (see among others Bech 2012; Los 2015; Pintzuk 2014), introducing a set of discourse elements that highlight given and new information. Hence, Petrova's research (2012) suggests that novel objects tend to appear postverbally, albeit she remarks that information structure cannot be safely identified as a governing factor for object placement. Another study of pragmatic factors indicates that OE adverbs like pa and ponne meaning 'then' mostly take discourse-linked element (given information) to the left (van Kemenade 2009).

(9) Hwæt ba se biscop hine blipelice gefullode, and ealle his

What then the sishop him blithely baptized, and all his

hiwan on pæs Hælendes naman.

Household in the Saviour's name.

'and indeed the bishop blithely baptized him and all his household in the

Savoiur's name.' (ÆLS: 167)

The use of pa in (9) illustrates that the focused part of the clause is introduced by the adverb/particle, which immediately precedes it. 
Taking into account various pragmatic factors B. Los (2015) hypotheses that Old English was a bounded language, suggesting that loss of boundedness was a consequence of losing the V2 word order.

Summarizing the main findings for OE (Walkden, 2017), it can be claimed that:

(a) The initial constituent in V2 and V3 clauses take a variety of forms (a CP, a DP, or a PP) and serves a variety of functions (van Kemenade and Los 2006: 229).

(b) The preverbal constituent in V3 clauses may frequently be a pronominal subject (Bech 2001; Haeberli 2002).

(c) The preverbal constituent in V3 clauses is always given information tagged as an aboutness Topic (Hinterhölzl\&Petrova 2009; van Kemenade\&Milicev 2012).

(d) V2 and V3 are characteristic of main clauses, subordinate clauses, however, do not regularly demonstrate this tendency.

(e) Only V2 word-order is found in wh-questions (van Kemenade 1987).

\subsection{Word Order in Middle English}

Middle English (ME) emerges as a different language than Old English due to the fact that it has fewer inflections to mark the function of words in a sentence. Kroch\&Taylor (1997) explain the loss of V2 as a result of the competition between the grammars of northern and southern dialects, with the former being heavily influenced by Scandinavian syntax that demonstrated a verb-medial order at that time. Based on data from South-east Midlands and West Midlands texts S. Pinzuk (2014) indicates that the latter exhibit a robust competition between OV and VO word orders, whilst South-east Midlands texts are largely OV (10).

(10) 7 te king it besæt

and the king it besieged

'and the king besieged it' (ME Peterb., 54:19 (1135)

Tripps (2002), however, proves that there are many diagnostics for underlying VO syntax in ME, supporting her hypothesis with findings from Ormulum and other ME works. The hypothesis that Early Middle English was already a verb-medial and VO language is proved in the studies by Koopman and Haeberli (2007) irrespective of the fact that there is a small number of verb-final clauses in Early Middle English texts, i.e., 1.1\% (Bech 2001: 68). Thus, there is no unanimity concerning the basic syntactic pattern in Early Middle English texts.

The Late Middle English seems the most heterogeneous with $86.1 \%$ of the clauses having either SVO, OSV or OVS word order (Bech 2001: 92). Notably, SVO and OVS clauses are characteristic of verb-medial syntax. It is particularly interesting that XSV pattern reaches $33.3 \%$, and SOV, SV1OV2, and verb-initial patterns almost disappear, which is again typical of verb-medial syntax. The conclusion drawn would be that verb-medial word-order, to a great extent, has become established in the XVcentury English.

Taking the stated above into account, the study, though being narrowed to sentences with adverb largely, focuses on such word order patterns and their variations as SVO, OSV, SOV, VSO, and VOS.

\section{Methods}

\subsection{The aim of the study}

The research reveals that the adverb can frequently occupy a post-modifying position in $28.2 \%$ of instances. Thus, it is proposed to single it out in the patterns taking into account its modification "route". These patterns have to be considered in relation to information novelty, Focus types in order to identify the existence of regular patterns for the adverb placement. 


\subsection{Information structure}

The term information structure presupposes the analysis of aspects of natural language that help speakers to take into consideration the addressee's or speaker's current information state and, therefore to facilitate the flow of communication (Krifka\&Mussan 2012). The examples are tested in view of two oppositions: given vs. new information, Topic vs. Focus (See among others Brunetti 2004; Cinque 2006; Krifka 2007; Speyer 2010).

Given is something that is being mentioned or is being taken up again, while new information has not been present in the immediate linguistic context before. A theory of givenness distinguishes several states: a discourse referent is completely new and non-identifiable for the hearer in case it is not represented in his memory. However, it can also be the case that it is not activated in his memory since the discourse referent has not been mentioned for a long time (Eitler\&Westergaard 2014).

E. Prince (1992) proposes two communicative perspectives: a speaker and a hearer. To identify informational types in the context, she applies the taxonomy of inferred familiarity as in (11).

(11) evoked > unused > inferable > containing inferable > brand-new anchored $>$ brand-new.

Hence, four informational types can be distinguished (See Table 2).

\begin{tabular}{l|c|l}
\hline Information & Hearer given (old) & Hearer new \\
\hline Discourse given (old) & Evoked & Not-registered \\
\hline Discourse new & Unused & Brand new \\
\hline
\end{tabular}

\section{Table 2. Types of Information in the Discourse}

In order to refer to the notion of givenness, it is crucial to building a file that consists of records of all the individuals (objects, events, etc.) mentioned in the text, which are called discourse referents (DRs). To annotate givenness, it is essential to keep track of the DRs (Lüdeling et. al 2016). So, the main idea is to decide whether NP introduces a DR or not. If there is no DR, there is no annotation. Once there is a DR, the tag is chosen based on its givenness status. Under the present study, information is tagged as given, which antecedents do not lie outside 13 sentence window (Haugh, Eckhoff \&Welo 2014: 36).

Firstly, we have to look at discourse context, viz. the discourse that precedes a certain utterance. The context contains previously mentioned DRs. In historical texts the discourse context should contain only the explicit contents of the previous discourse, not inferences and implicatures that it gives rise to (Haug et. al 2017: 24).

(12) My lordes sayd syre Launcelot wete yow wel / I haue ben euer syns I came in to this Countrey wel wylled vnto my lord kynge Arthur / and vnto my lady Quene Gueneuer vnto my power / and this nyghte by cause my lady the quene sente for me to speke with her.

NP my lady quene is mentioned in the previous sentence, so it is discourse given; pronoun her evidently refers to NP my lady quene therefore it is also tagged as discourse given.

Secondly, there is a scenario context that contains knowledge that licenses indirect anaphora (13).

(13) Syr launcelot said the kyng ouer moche haue ye said to me / and I haue sworne and said ouer largely afore kyng Arthur in herynge of alle his knyghtes / that I shal not sle nor bitraye hym (Le Morte Darthur).

Considering DR Arthur's knights we assume that they are known to the reader based on the knowledge from the previous context despite the fact that they represent information which antecedents lie outside 13 sentence window. Thus, we assume that based on the entire reading of Le Morte Darthur the hearer knows that the king has knights. 
Thirdly, we have to take into account encyclopedic context, i.e., the knowledge shared by the speaker (author) and the hearer (reader). The author relies on the audience being able to resolve the reference (14).

(14) For zif man suffre to pe deep on good maner in Goddis cause, 3 it he hap ay-lastyng lyf, pat is beter pan al his zifte. For God of his grete lordship cannot rewarde but largely, as an erpely lord for litil rewardip men bi more mede. And pus clerkes seien comounly, pat a man disservep on two maneris, covenabli and even-worpily. On pe first maner a man disservep blis; for it is covenable to God, worpi and just bope, pat he of his greet grace rewarde largely his pore servaunt (PE FORDE SONDAI DISTLE AFTIR TRINITE. S.XXXIV.: 323-324).

Since the text focuses on clerical issues, the author presupposes that the reader is familiar with such notions as God, Goddis cause, erpely lord, pore servaunt, though the latter two are not given in the previous discourse, they are a part of common ground knowledge and are contextually evoked.

The Corpus annotation is based on Discourse Representation Theory. This methodology was applied to annotate givenness in PROIEL corpus, a corpus of old Indo-European New Testament translations (Haug et al. 2009; Lavidas et al. 2020). Similar annotation was also applied for tagging IS categories in Tatian Corpus of Deviating Examples (T-CODEX Petrova et al. 2009). The tags proposed are given in Table 3.

\begin{tabular}{l|l|l}
\hline Layer & Tags & Short description \\
\hline Information status & giv & given (underspecified) \\
\cline { 2 - 3 } & giv-active & active \\
\cline { 2 - 3 } & giv-inactive & inacttive \\
\cline { 2 - 3 } & acc & accessible (underspecified) \\
\cline { 2 - 3 } & acc-sit & situationally accessible \\
\cline { 2 - 3 } & acc-inf & inferrable \\
\cline { 2 - 3 } & acc-gen & general \\
\cline { 2 - 3 } & new & non-specific \\
\hline
\end{tabular}

Table 3. Tags of the Extended Annotation Scheme for Information Structure

The informational status of linguistic expressions is also determined in relation to the dimensions of topicality and focality. Linguists, however, have not reached a consensus as to the common definition of these terms. The topic has been assumed to be a part of the sentence that conveys old information (Sánchez 2010). This idea seems to be problematic because Topic may represent discourse-new information:

(15) FOR als moche as the lond bezonde the see pat is to seye the holy lond pat men callen the lond of promyssioun or of beheste passynge att opere londes it is the most worthi lond most excellent and lady \& soucreyn of att opere londes $\&$ is blessed $\&$ halewed of the precyous body $\&$ blood of oure lord jhssu crist; jn the whiche land it lykede him to take flesch \& blood of the virgyne Marie to envyrone pat holy lond with his blessede feet (Mandeville's travels: the Cotton version)

The NP the lond (land) is a discourse-new referent that starts the story of Mandeville's travels, functioning as the Topic of the sentence, the author obviously refers to it as discourse-new referent providing further explanation, what kind of land it is: callen the lond of promyssioun or of beheste passynge, the most worthi lond most, etc.

Pragmatic definition of Topic is as follows "the part of the clause that denotes discourse accessible information that is the matter of common concern for the speaker and the addressee." (Pereltsvaig 2004: 327). To provide a more simplified notion of Topic we confine to Frascarelli\&Hinterhölzl's (2007) definition, viz. "the subject of predication, what the sentence 'is about'. The rest of the sentence represents

XLinguae, Volume 14 Issue 2, April 2021, ISSN 1337-8384, eISSN 2453-711X 
comment, i.e., the part of the sentence which is predicated about the Topic. Neeleman $\&$ Vermeulen (2012) propose the further partition of Topics into aboutness (16) and contrastive (17) ones, which is also relevant for the current studies. As to the latter they represent a combination of Topic and Focus, hence consisting of an aboutness Topic that contains a Focus. In this case a contrastive Topic indicates an alternative aboutness Topic.

(16) He prayeth him in his causë to procede,

And largely guerdoneth he his travayle;

Smal witen wommen how men hem assayle! (The complete works of Geoffrey Chaucer)

(17) ANd after, hit bifelle pus at Ester, pere he helde a feste at Parys; richely he gan auaunce his kny3tes for here seruise pat him hade holpen in his conquest; he zaf to his stywarde bat men cleped Kay, Angon \& Angers, and to Bedeler his boteler he zaf Normandye, pat po was callede Neustrie; and to Holden his chaumberleyn he zaf Flaundres and Mance; and to Dorell his cosyn he zaf Boloyne; and to Richard his Nevew he zaf Pountif; And to alle opere he zaf largely landes \& fees after pat pai were of state. The Brut, or The chronicles of England)

The expert in (17) relates how the lands were allotted by the king, indicating persons and what they received from the king. The NP to alle opere (to all other) represents a contrastive Topic in this sense referring to the set of alternatives. The NP is tagged as NEW.

Focus that is traditionally associated with novelty, however, there are always cases in which a constituent that refers to something mentioned previously is in Focus (18).

(18) A: Who stole the cookie, John or Mary?

B: JOHN stole the cookie.

To avoid this ambiguity, the status of Focus should be attached to those pieces of information which represent the most important or salient information (Gómez González 2001: 143). As regards sentence (JOHN) this means that Focus indicates the presence of alternatives relevant for the interpretation of linguistic expressions. Focus can be further subdivided into informational, identificational, emphatic, exhaustive, contrastive and verum Focus.

Informational Focus (19) is the part of the sentence with a great level of novelty, following Jackendoff's (1972) definition, it is information that is not shared by a speaker and a hearer.

(19) And so the emperoure trowed his counsaile, and departed his goodes, and gaue it largely for the loue of God (Book of the Knight of La TourLandry).

The NP for the loue of God (for the love of God) is not mentioned in the previous discourse thus representing New information.

The notion of contrast is traditionally applied to such phenomena like correction, selection or emphasis, is viewed as involving the presence of alternatives that are explicitly mentioned in the discourse (Neeleman\&Vermeulen (2012). In our study contrastive Focus is restricted to Focus used for purely contrastive purposes, which presupposes that the common ground contains a proposition with which the utterance can be contrasted (20).

(20) But aftir pis firste sone was moved of God bi kyndely skile to serve him and lyve wel, as in Joob and Jetro, but largely whanne hepene men token bi apostlis Cristis feip. (Select English works of John Wyclif)

Identificational Focus, in terms of Kiss (1998), expressing identity statement, is associated with the presence of alternatives given in the previous discourse and does not need to have a contrastive interpretation (though it may).

(21) The place at Warwykys Inne is large and my grawntdame is agyd; it had ben jopartous to leve moche plate wyth hyre, thoghe halffe were hyre 
owne. But iff I maye doo other wyse I purpose nott to chevyshe any mony by hys meane. Item, I have delyueryd yowre botell to Courbye pe caryere thys same daye, and he promysed me to be wyth yow on Mondaye nyghte ore ellys on Towesday tymely. He hathe also xl d. to paye fore the thryd hyryd horse, and he bryngythe the iij horse wyth hym and is contente for hys labore and for the mete largely. (Paston letters and papers of the fifteenth century)

The NPs for his labor and for the meet (food) has not been mentioned in the discourse and can be tagged as acc-sit, since it is inferred from the previous sentences that the person is doing a kind of work.

Emphatic Focus (scalar Focus) presupposes the establishment of a scale values, and targets the extreme value on the scale, signaling that the assertion is either surprising or exceptional. (Viviane Déprez, Espinal 2020: 554).

(22) And largëly we wul zow zyue, 8963

And wurschyp pys stede whyl pat we lyue; (Robert of Brunne's "Handlyng synne")

In sentence (22) adverb largely marks emphatic Focus expressed by Pro we tagged as giv-active, since it was mentioned previously.

Exhaustive Focus indicates that the Focus denotation is the only one that leads to a true proposition (Hill\&Alboiu 2016: 73; Schwabe\&Winkler 2007: 161).

(23) And Jesus seide to him, bou hast seen him, and it is he pat spekip wip

pee. (Select English works of John Wyclif)

As stated in the sentence (23) nobody else but Jesus speaks to a person (Pro he is focused). Consequently, exhaustive Focus is tagged as giv-active.

Verum Focus represents the truth value of a sentence, which may be expressed by accenting an auxiliary (Frascarelli\&Hinterhölzl 2007). In Middle English texts, unlike in Modern English, it seems problematic to single out emphatic auxiliaries, but still examples like (24) can illustrate the truth condition of the proposition.

(24) Furth thei russhed a grete pas *. [and sets off to overtake Clarionas.]

To ouertake feire [Clarionas]

And the lauender alsoo

Or thei cam the water too; [7240]

And so thei did at the last.

For [Generides] rode not fast. (A royal historie of the excellent knight Generides)

Table 4 summarizes the tags applied to the analysis of the second type of dichotomy, viz. Topic/Focus.

\begin{tabular}{l|l|l}
\hline Layer & Tags & Short description \\
\hline \multirow{3}{*}{ Topic } & ab & aboutness topic \\
\cline { 2 - 3 } & ct & contrastive topic \\
\hline & inf & informational focus \\
\cline { 2 - 3 } & idf & identificational focus \\
\cline { 2 - 3 } & cf & contrastive focus \\
\cline { 2 - 3 } & emph & emphatic focus \\
\cline { 2 - 3 } & exhf & exhaustive focus \\
\cline { 2 - 3 } & cf-ver & verum focus \\
\hline
\end{tabular}

Table 4. Tags of the Annotation Scheme for Topic/Focus

\section{Results and discussion}

The study uses a quantitative method to examine the clause structure with the adverb largely singled out from the Corpus which is based on attaching tags for givenness and Topic/Focus variations. The total number of matches found in the entire Corpus 
made 378, out of which 142 instances represent largely as a focusing adverb. We examine every word order pattern to determine some regularities for largely placement with reference to tagging information structure in the sentence. Verb medial order is reflected in our data with SVO pattern amounting to $83.8 \%$, SOV order sentences account to $3.5 \%$, OSV $-8.5 \%$, VSO $-2.8 \%$ and VOS $-1.4 \%$ respectively.

\section{1. $\mathrm{SV}(\mathrm{O})$ pattern}

The pattern amounts to $83.8 \%$ in the study and for its convenience we represent the adverb separately in each pattern. Hence, the registered word order patterns look like this: $\mathrm{S}(\mathrm{v}) \mathrm{V}(\mathrm{O})$ largely->O, S largely- $>(\mathrm{v}) \mathrm{VO}, \mathrm{Sv}<-$ largely- $>\mathrm{VO}, \mathrm{SVO}<-$ largely, $\mathrm{SV}<-$ largely, largely->S(v) VO, SvO largely->V.

Tagging information structural components for the pattern $S(v) V(O)$ largely->O we found the following regularity: in $80 \%$ of instances largely marks new information (new) and informational Focus (inf). The Topic is tagged as ab (aboutness) in all the instances (25).

(25) Also sche loved moche Goddes service, perfore sche spended moche on clerkes bat kowpe wel synge. berfore famous men of scole come to here wip vers*. [versus, Cx.] and wip song, as it were out of alle londes. Also sche spendede largeliche on comers pat come on every side. (Polychronicon Ranulphi Higden maonachi Cestrensis)

The annotation of the sentence IS with adverbial looks as follows: Also sche [givactive, ab] spendede [new] [largeliche on comers [new, inf]]

With other $20 \%$ of instances the information marked by largely is tagged as acc-inf (inferable) and the element presents idf (identificational Focus). The sentence Topic is tagged as ab (26).

(26) My lord, I trust that your lordshepe shall lyek bothe ther persones and ther condicyons, and as for ther trowthes, if it may please your good lord shepe to accept my poore woord wyth thers, I wyll depose largely for that. (Paston letters and papers of the fifteenth century)

Sentence annotated IS structure: I [giv-active, ab] wyll depose [new] [largely for that [acc-inf, idf]].

Another widespread pattern is SVO--largely in which $100 \%$ of instances demonstrate the following regularity: the component marked by largely is tagged as giv (givenactive), representing idf. Sentence Topic in $100 \%$ is given (giv-active) being tagged as ab.

(27) At morn $y^{*}$. [In pe mornynge at.] pe sonne rysynge,

Brutus led Pandras pe kynge 1188

Vntil his*. [won.] castel, his owen hold,

\& dide hym kepe wip knyghtes bold.

Sypen tok Brutus al pe tresour

Pat he had wonnen*. [won.] yn pat stour, 1192

$\&$ gaf his knyghte largely,

$\&$ als til oper fol corteysly.*. [\& oper yerof had curtasy.]

(The story of England)

Sentence IS annotation: Pat he [giv-active, ab] had wonnen*. [new] yn pat stour [givactive], \& gaf [new] [his knyghte [giv-active, idf] largely]

The study of the left dislocated adverb in the pattern largely->S(v)VO indicates that it highlights given information mostly represented by a subject-pronoun that functions as emphatic Focus (emph) in $100 \%$ of the examples analyzed. The sentence Topic is tagged as ab (28).

(28) He sought aboute in pat contre tho

Where any almes myght be do,

And largely he dud hem yeue, 
Wayes \& brugges for to make,

And pore men for goddis sake 215

He yeaf them gret releve.

(Altenglische legenden)

Sentence IS annotation: And [largely he [giv-active, emph]] dud [new] hem [givactive, ab] yeue [new], [Wayes \& brugges for to make [new]]

Traditionally, the patterns where largely marks the verb (S largely->(v) $\mathrm{VO}, \mathrm{Sv}<-$ largely->VO, SvO largely- $>\mathrm{V}$ ) signify that the latter is new information in the discourse representing informational Focus (29)-(30). It is indicative that the adverbial occupies in these patterns a pre-modifying position.

(29) Be come my man, and thu wilt do so

The pese shall sone be twix vs twoo. 3416

I shall also in wurchippe the avaunce, 3417

And largely $\rightarrow$ departe with the also;

(Generydes, a romance in seven-line stanzas).

Sentence IS annotation: I [giv, ab] shall [new] also in wurchippe [new] the avaunce [new], And [largely $\rightarrow$ departe [new, inf]] with the [giv]] also

(30) But the myght and the wysdome of that blessyd lorde god was soo gretely shewed to the pharyzens whiche accused her that they so largely perceyued theyr synnes that they myght not for shame deme her but stale awaye out of the temple

(Companion to the English prose works of Richard Rolle)

Sentence IS annotation: that they [giv, ab][so largely perceyued [new, inf] theyr synnes [giv]].

With post-modifying position of adverbial when marking the verb, we find no regularity, since in $62.5 \%$ of instances in the model SV<-largely the adverbial marks given information and idf (31). For the rest of the patterns $\mathrm{V}$ in question represents either new of acc-sit information and inf (32).

(31) For God of his grete lordship cannot rewarde but largely, as an erpely lord for litil rewardip men bi more mede. And pus clerkes seien comounly, pat a man disservep on two maneris, covenabli and even-worpily. On pe first maner a man disservep blis; for it is covenable to God, worpi and just bope, pat he of his greet grace rewarde $\leftarrow$ largely his pore servaunt (Select English works of John Wyclif. Vol. 2)

Sentence IS annotation: pat he [giv, ab ]of his greet grace [new] rewarde [giv, idf] $\longleftarrow$ largely his pore servaunt [giv].

(32) The hiznesse of housis schal be maad low in slouthis; and the hous schal droppe*. [the hows schal droppe, etc.; that is, in the slouthe of hondis fro goode werkis. Lire here. C.] in the feble|nesse of hondis. [verse 19] In leizyng thei disposen*. [In leizing thei disposyn, etc.; that is, vnco|uenablemyrthe. Lire here. C.] breed and wyn, that thei drynk|ynge largeli; (Select English works of John Wyclif).

Sentence IS annotation: that thei [giv, ab] [drynk|ynge [acc-sit, inf] largeli]

Figure 2 summarizes the findings for SVO word order patterns with the adverb largely, since Topic types proved not to have any effect on word-order patterns we excluded them in the table. Some patterns with largely marking the verb were also grouped together. 


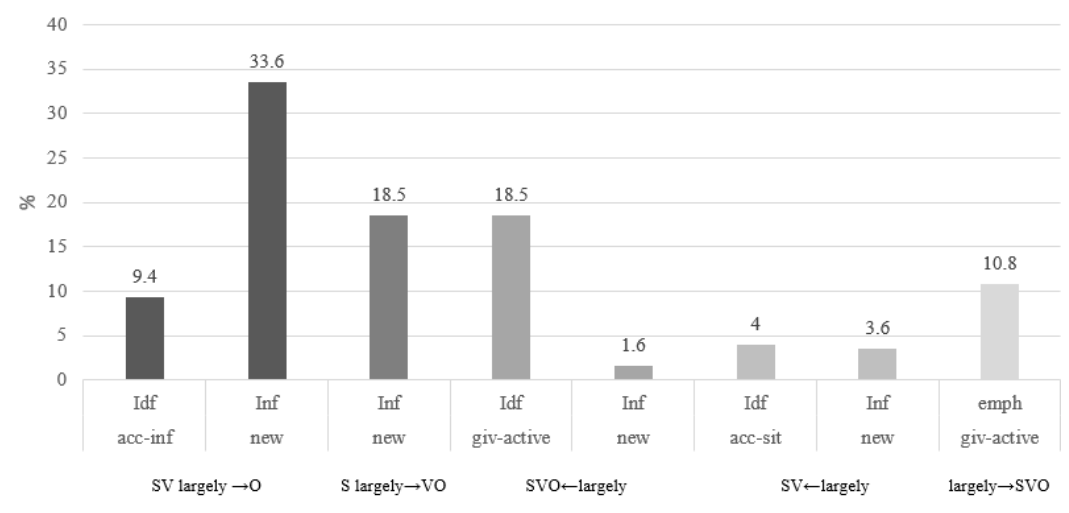

\section{Figure 2. Word-Order and Information Structure Distribution with Adverb largely for SVO Pattern}

Investigation of the position of largely signifies that it occupies a post-modifying position when the element marked by the adverb is given and presents identificational Focus $(100 \%)$. A pre-modifying positions are characteristic of largely marking given information and emphatic Focus. The same is true for the majority of instances in which adverbial marks new information and informational Focus (91.4\%). When largely highlights situationally accessible information and identification Focus, there is no certain regular pattern, though this adverbial oftentimes occupies a premodifying position $(62.5 \%)$.

\subsection{OSV pattern}

The OSV word order pattern amounts to $8.5 \%$ in our data and is represented by such models as OSV largely->O (33.3\%), largely-> OSV (41.7\%), OSv<-largely->V $(16.7 \%)$ and OSV<-largely $(8.3 \%)$. What seems peculiar for these patterns is that despite information novelty, the object that precedes the subject represents a contrastive Topic (33).

(33) ANd after, hit bifelle pus at Ester, pere he helde a feste at Parys; richely he gan auaunce his kny3tes for here seruise pat him hade holpen in his conquest; he zaf to his stywarde pat men cleped Kay, Angon \& Angers, and to Bedeler his boteler he zaf Normandye, pat po was callede Neustrie; and to Holden his chaumberleyn he zaf Flaundres and Mance; and to Dorell his cosyn he zaf Boloyne; and to Richard his Nevew he zaf Pountif; And to alle opere he zaf largely landes \& fees after pat pai were of state (The Brut, or The chronicles of England)

Sentence IS annotation: And [to alle opere [giv-active, ct] he [giv-active, ab] 3 af [new] [largely landes \& fees [new, inf]].

As to Foci types marked by adverb largely in $58.4 \%$ of instances it refers to new information and informational Focus (34), preceding the element it highlights but one example. In other $33.3 \%$ of instances largely identifies contrastive Focus (35), preceding the object which is given information, while only $8.3 \%$ of sentences have largely that marks emphatic Focus (36).

(34) oF the vertu of Iustice afor in this boke Is largely Saydyn̄, but for-alsmoche as Aristotle-is boke makyth [folio $58 \mathrm{bL}$ ] mencion of Iustice, the best wordys that therin benne I shall here-to youre nobellese writte. Iustice Is a vertue that mych is to Preyse for hit is appropyrte of the glorious god (TO JOHN PASTON II 1476, 02, 03).

Sentence IS annotation: [oF the vertu of Iustice [acc-sit, ab] afor in this boke [givactive, ab] [Is largely Saydyn̄ [new, inf]].

(35) Ac suppe as vnstable man · wip sede $\&$ wip drou $\cdot$ 
\& wanne him muche strange folc $\cdot$ of bizonde se $\cdot$

$\&$ some as god it wolde $\cdot$ ne come neuere aze

$\&$ largeliche $\rightarrow$ hom 3 ef inou $\cdot$ of is barones londe

$\&$ is castles aboute $\cdot$ tok hom vaste an honde $\cdot 10,511$ (The metrical chronicle of Robert of Gloucester)

Sentence IS annotation: \& [largeliche $\rightarrow$ hom [giv-active, cf] 3 ef inou [new] of is barones londe [giv-active]

(36) For god had bidden him on pis wise

Pat he suld strike on pe flint twise,

And largely ban suld it gif

Water pat pai with might lif; 452

(Legends of the holy rood; Symbols of the passion and cross poems).

Sentence IS annotation: And [largely pan [giv-inactive, emph] suld [acc-inf] it [givactive, ab] gif [acc-inf] Water [new]

To make a preliminary conclusion, OSV pattern is mostly used with largely in case we have a contrastive Topic, making Topic tagging relevant for this pattern. Foci types highlighted by largely are represented by informational, contrastive and emphatic Focus. In $83.3 \%$ of instances the adverb precedes the word it marks as Focus, and only in $16.7 \%$ it occupies a postmodifying position (mostly when it comes to highlighting a contrastive Focus).

\subsection{Minor patterns SOV, VOS and VSO}

The sentences with the abovementioned word-orders are represented only by a few instances, which makes it difficult to point to some regularities in their usage. We would rather specify the general tendency for them.

SOV pattern, represented by such variants as SOV<-largely, SOv<-largely->V, SO largely- $>V$, SOV largely $\rightarrow X$, is registered mostly in subordinate clauses only amounting to $3.5 \%$ of our data. The adverb largely marks mostly the verb that represents new information and informational Focus, while Topic is tagged as ab and is given information.

(37) Is brother Edward and he associate

To Ierusalem their voiage thē auowed,

Two semely princes together adioynate [adunate.],

In all the world was none theim like alowed,

So large \& faire thei were, eche manne he [theym.] bowed;

Edward aboue [abouyn.] his menne was largely seen,

By his shulders more hie and made full clene.

(The chronicle of Iohn Hardyng)

Sentence IS annotation: Edward [giv-active, ab] [aboue his menne [giv-active]] [was<-largely-> seen [new, inf]].

Peculiar for this pattern is a pre-modifying position of adverbial in $80 \%$ of instances and only in $20 \%$ of examples largely occupies a postmodifying position.

Patterns with VSO (2.8\%) and VOS (1.4\%) word orders demonstrate a pre-modifying position of largely marking the VP in $100 \%$ of instances that is tagged as acc-sit and contrastive Focus (38).

(38) Beuys is nowe of great myght

And loued both of kynge and knyght,

Wyth euery knyght, squyer and barowne,

Beuys was loued vp and downe,

For largely wolde he spende 3251

And gyftes both gyue and sende 3252

To euery man after his estate;

(The romance of Sir Beues of Hamtoun) 
Sentence IS annotation: For [largely wolde [acc-sit, cf] he [giv-active,ab] spende [accsit, cf]] And gyftes [giv] [both gyue and sende [[acc-sit, cf]] [To euery man after his estate [new]].

\section{Concluding remarks}

The study investigated word-order patterns with adverbs largely in Late Middle English, viz. SVO, OSV, SOV, VSO and VOS. The findings reveal dominant word orders registered with the adverb, i.e., SVO and OSV, which are characteristic of verb-medial syntax. The research also looked at information novelty and Topic/Focus marking in every pattern, considering largely placement in relation to the element it marks.

The study shows that though word-order patterns vary significantly, they demonstrate general tendencies for adverb placement. Thus, when marking new information and informational Focus largely mostly occupies a pre-modifying position and is traced with SVO, SOV and partially with OSV patterns. Significantly, the latter word-order is relevant when the object represents a contrastive Topic. When the adverb highlights given information and identificational Focus its post-modifying position in SVO pattern is most regular. VSO and VOS patterns are encountered when VP presents a contrastive Focus with largely in a pre-modifying position.

Since Middle English period shows only the standing of the focusing adverb it is worthwhile to examine these tendencies in further centuries when data selection is more representative.

\section{Bibliographic references}

ANDRUSHENKO, O. 2017. Information-structural impact on adverbial only evolution in the Middle English language. In: Science and Education, a New Dimension. Philology, vol. 5 (29), n. 116, pp.10-15. ISSN 2308-5258.

BECH, K. - EIDE, K. G. (Eds.). 2014. Information Structure and Syntactic Change in Germanic and Romance Languages. Amsterdam; Philadelphia: John Benjamins Publ. ISBN 9789027270467.

BECH, K. 2001. Word Order Patterns in Old and Middle English: A Syntactic and Pragmatic Study, PhD dissertation. Bergen: University of Bergen. ISBN 82-4970005-8.

BECH, K. 2012. Word order, information structure and discourse relations: A study of Old and Middle English verb-final clauses. In: A. Meurman-Solin, M. J. LopessCouso \& B. Los (Eds.), Information Structure and Syntactic Change in the History of English, pp. 66-86. Oxford: Oxford University Press. ISBN 9780199860210.

BRITISH NATIONAL CORPUS. 2021. Available online: https://www.englishcorpora.org/bnc/.

BRUNETTI, L. 2004. A Unification of Focus. Padua: Unipress. ISBN 978-88-8098209-8.

CINQUE, G. 2006. Restructuring and Functional Heads. Oxford: Oxford University Press. ISBN 9780195179545.

CORPUS OF MIDDLE ENGLISH PROSE AND VERSE (2019). Available online: https://quod.lib.umich.edu/c/cme/.

DÉPREZ, V. - ESPINAL, T. M. 2020. The Oxford Handbook of Negation. Oxford: Oxford University Press. ISBN 9780198830528.

EITLER, T. - WESTERGAARD, M. 2014. Word order variation in late Middle English: The effect of information structure and audience design. In: K. Bech, K. G. Eide (Eds.), Information Structure and Syntactic Change in Germanic and Romance Languages,), pp. 203-232. Amsterdam; Philadelphia: John Benjamins Publ. ISBN 9789027255969. 
FOOLEN, A. 1993. De betekenis vanpartikels: Een dokumentatie van de stand van het onderzoek met bijzondere aandacht voor jnaar, $\mathrm{PhD}$ dissertation. Nijmegen: University of Nijmegen. ISBN 903730186X.

FORKER, D. 2016. Toward a typology for additive markers. In: Lingua, vol. 180, pp. 69-100. ISSN 0024-3841. DOI: 10.1016/j.lingua.2016.03.008.

FRASCARELLI, M. - HINTERHOLZL, R. 2007. Types of topics in German and Italian. In: K. Schwabe, S. Winkler (Eds.), On Information Structure, Meaning and Form: Generalizations Across Languages, pp. 87-116. Amsterdam; Philadelphia: John Benjamins Publ. ISBN 9027233640. DOI: 10.1075/la.100.07fra.

GAST, V. - AUWERA, J. van der. 2011. Scalar additive operators in the languages of Europe. In: Language, vol. 87, n. 1, pp. 2-54. ISSN 1535-0665. DOI: 10.1353/ lan.2011.0008.

GOMEZ-GONZALEZ, M. A. 2001. The Theme-Topic Interface: Evidence from English. Amsterdam; Philadelphia, John Benjamins Publ. ISBN 9789027250865.

HAEBERLI, E. 2002. Inflectional morphology and the loss of V2 in English. In: D. Lightfoot (Ed.), Syntactic Effects of Morphological Change, pp. 88-106. Oxford: Oxford University Press. ISBN 9780199250691. DOI: 10.1093/acprof:oso/ 9780199250691.001.0001.

HAUG, D. - ECKHOFF, H. M. - MAJER, M. - WELO, E. 2009. Breaking down and putting back together: analysis and synthesis of New Testament Greek. In: Journal of Greek Linguistics, vol. $\quad 9, \quad$ n. $\quad 1, \quad$ pp. 56-92. DOI: $10.1163 / 156658409 \times 12529372103308$.

HAUG, D. - ECKOFF, H. - WELO, E. 2014. The theoretical foundations of givenness annotation. In: K. Bech, K. G. Eide (Eds.), Information Structure and Syntactic Change in Germanic and Romance Languages, pp. 17-52. Amsterdam; Philadelphia: John Benjamins Publ. ISBN 9789027255969. DOI: 10.1075/la.213.

HELBIG, G. 1988. Lexikon deutscher Partikeln. Leipzig: VEB Verlag Enzyklopadie. ISBN 103324003105.

HILL, V. - ALBOIU, G. 2016. Verb Movement and Clause Structure in Old Romanian. Oxford: Oxford University Press. ISBN 9780198736509. DOI: 10.1093/acprof:oso/ 97801987365 09.001.0001.

HINTERHOLZL, R. - PETROVA, S. 2009. From V1 to V2 in West Germanic. In: Lingua, vol. 120, pp. 315-328. ISSN 0024-3841. DOI: 10.1016/j.lingua.2008.10.007.

JACKENDOFF, R. 1972. Semantic Interpretation in Generative Grammar. Cambridge MA: MIT Press. DOI: 10.1017/S0022226700004394.

KEMENADE, A. van. - LOS, B. 2006. Discourse adverbs and clausal syntax in Old and Middle English. In: A. van Kemenade \& B. Los (Eds.), The Handbook of the History of English, pp. 224-248. Oxford: Blackwell Publ. ISBN 0-631-23344-X.

KEMENADE, A. van. - MILICEV, T. 2012. Syntax and discourse in Old and Middle English word order. In: D. Jonas, J. Whitman \& A. Garrett (Eds.), Grammatical Change: Origins, Nature, Outcomes, pp. 239-254. Oxford: Oxford University Press. ISBN 978-0199582624. DOI:10.1093/acprof:oso/9780199582624.003.0012.

KEMENADE, A. van. 1987. Syntactic Case and Morphological Case in the History of English. Dordrecht: Foris Publications. ISBN 906765342X.

KEMENADE, A. van. 2009. Discourse relations and word order change. In: R. Hinterhölzl \& S. Petrova (Eds.), Information Structure and Language Change: New Approaches to Word Order Variation in Germanic, pp. 91-118. Berlin; New-York: Mouton de Gruyter. ISBN 9783110205916. DOI: 0.1515/9783110216110.

KISS, K. E. 1998. Identificational focus versus information focus. In: Language. Journal of the Linguistic Society of America, vol. 74, pp. 245-273. DOI: $10.2307 / 417867$. 
KRIFKA, M. - MUSAN, R. 2012. The Expression of Information Structure. Berlin; New-York: Mouton de Gruyter. ISBN 9783110260083. DOI: $10.1515 / 97831102$ 61608.

KRIFKA, M. 2007. Basic notions of information structure. In: F. Fery \& M. Krifka (Eds.), Interdisciplinary Studies on Information Structure 6, pp. 13-55. Potsdam: Universitatsverlag Potsdam. ISBN 978-3-939469-88-9.

KROCH, A. - TAYLOR, A. 1997. Verb movement in Old and Middle English: dialect variation and language contact. In: A. van Kemenade \& N. Vincent (Eds.), Parameters of Morphosyntactic Change, pp. 297-325. Cambridge: Cambridge University Press. DOI: 10.1017/S0022226799258045.

LAVIDAS, N. - TRUSLEW, H. D. T. 2020. Postclassical Greek and treebanks for a diachronic analysis. In: D. Rafiyenko \& Ilja Seržant (Eds.), Postclassical Greek: Contemporary Approaches to Philology and Linguistics, pp. 163-202. Berlin: Walter de Gruyter. ISBN 978-3-11-067672-3.

LOS, B. - KEMENADE, A. van. 2012. Information structure and syntax in the history of English. In: A. Bergs \& L. Brinton (Eds.), English Historical Linguistics: An International Handbook, vol. 2, pp. 1475-1489. Berlin; New-York: Mouton de Gruyter. ISBN 978-3-11-020265-6.

LOS, B. 2015. A Historical Syntax of English. Edinburgh: Edinburgh University Press. ISBN 10 0748641440. DOI: 10.1515/ang-2016-0008.

LÜDELING, A. - RITZ, J. - STEDE, M. - ZELDES, A. 2016. Corpus linguistics and information structure research. In: C. Fery \& Sh. Ishihara (Eds.), The Oxford Handbook of Information Structure, Oxford: Oxford University Press. pp. 599-620. ISBN 9780199642670. DOI: 10.1093/oxfordhb/97801996426 70.013.013.

NEELEMAN, A. - VERMEULEN, R. 2013. The syntactic expression of information structure. In: A. Neeleman \& R. Vermeulen (Eds.), The Syntax of Topic, Focus, and Contrast: An Interface-Based Approach, Berlin: Walter de Gruyter. pp. 1-38. ISSN 0167-4331. DOI: 10.1515/9781614511458.

PERELTSVAIG, A. 2004. Topic and focus as linear notions: evidence from Italian and Russian. In: Lingua, vol. 114, n. 3, pp. 325-344. ISSN 0024-3841. DOI: 10.1016/ S0024-3841(03)00029-9.

PETROVA, S. - SOLF, M. - RITZ, J. - CHIARCOS, C. - ZELDES, A. 2009. Building and using a richly annotated interlinear diachronic corpus: the case of Old High German 'Tatian'. In: Traitement automatique des langues, vol. 50, n. 2, pp. 4771. ISSN 1965-0906.

PETROVA, S. - SPEYER, A. 2011. Focus movement and focus interpretation in Old English. In: Lingua, vol. 121, n. 11, pp. 1751-1765. ISSN 0024-3841. DOI: 0.1016/j.lingua.2011.06.004.

PETROVA, S. 2009. Information structure and word order variation in the Old High German Tatian. In: R. Hinterhölzl \& S. Petrova (Eds.), Information Structure and Language Change, pp. 251-279. Berlin: Mouton de Gruyter. ISBN 9783110205916. DOI: $10.1515 / 9783110216110$.

PETROVA, S. 2012. The impact of focusing and defocusing on word order: changes at the periphery in Old English and Old High German. In: T. Nevalainen \& E. C. Traugott (Eds.), The Oxford Handbook of the History of English, pp. 846-58. Oxford, Oxford University Press. ISBN 9780199922765. DOI: 10.1093/oxfordhb/97801999227 65.013.0069.

PINTZUK, S. 2015. Phrase Structures in Competition: Variation and Change in Old English Word Order. New-York: Routledge. ISBN 9781138978454.

PRINCE, E. 1992. The ZPG letter: subjects, definiteness, and information status. In: S. Thomson \& W. Mann (Eds.), Discourse Description. Diverse Linguistic Analyses of a Fund-Raising Text, pp. 295-325. Amsterdam; Philadelphia: John Benjamins Publ. ISBN 9789027250315. DOI: 10.1075/pbns.16.12pri. 
QUIRK, R. - GREENBAUM, S. - LEECH, G. - SVARTVIK, J. 1985. A Comprehensive Grammar of the English Language. London: Longman. ISBN 0582517346.

RINGE, D. - TAYLOR, A. 2014. The Development of Old English. Oxford: Oxford University Press. ISBN 9780199207848.

SANCHEZ, L. 2010. The Morphology and Syntax of Topic and Focus: Minimalist Inquiries in the Quechua Periphery. Amsterdam; Philadelphia: John Benjamins Publ. ISBN 9789027287526. DOI: 10.1075/la.169.

SCHWABE, K. - WINKLER, S. (Eds.). 2007. On Information Structure, Meaning and Form. Amsterdam; Philadelphia: John Benjamins Publ. ISBN 9789027233646. DOI: $10.1075 /$ la.100.

SPEYER, A. 2010. Topicalization and Stress Clash Avoidance in the History of English. Berlin: Walter de Gruyter. ISBN: 9783110220247 . DOI: 10.1515/97831 10220247.1.

TAYLOR, A. 2014. Old English syntax. In: D. Ringe \& A. Taylor (Eds.), The Development of Old English, pp. 392-509. Oxford: Oxford University Press. ISBN 9780199207848.

TRIPS, C. 2002. From OV to VO in Early Middle English. Amsterdam; Philadelphia: John Benjamins Publ. ISBN 9789027296276. DOI: 10.1075/la.60.

WALKDEN, G. 2014. Syntactic Reconstruction and Proto-Germanic. Oxford: Oxford University Press. ISBN 9780198712299.

WALKDEN, G. 2015. Verb-third in early West Germanic: A comparative perspective. In: Th. Biberauer \& G. Walkden (Eds.), Syntax Over Time: Lexical, Morphological and Information-Structural Interactions, pp. 236-248. Oxford: Oxford $\begin{array}{llll}\text { University } & \text { Press. } & \text { ISBN } & \text { DOI: }\end{array}$ 10.1093/acprof:oso/9780199687923.003.0014.

WALKDEN, G. 2017. Language contact and V3 in Germanic varieties new and old. In: Journal of Comparative Germanic Linguistics, vol. 20, pp. 1-33. ISSN 1383-4924. DOI 10.1007/s10828-017-9084-2.

Words: 7631

Characters: 48490 (26,94 standard pages)

Olena Andrushenko

Depatment of Germanic and Finno-Hungarian Philology

named after Prof. G.G. Potcheptsov

Kyiv National Linguistic University

73 V. Vasylkivska str., 03680 Kyiv

Ukraine

olena.andrushenko@knlu.edu.ua 